\title{
СТРУКТУРНО-СЕМАНТИЧНА ТА ЕТНОКУЛЬТУРОЛОГІЧНА ХАРАКТЕРИСТИКА СОМАТИЗМІВ (НА ПРИКЛАДІ ФРАЗЕМ ІЗ КОМПОНЕНТОМ ОКО)
}

Кевлюк I. В. Структурно-семантична та етнокультурологічна характеристика соматизмів (на прикладі фразем із компонентом око).

У статті висвітлюються питання особливостей функціонування фразем із соматичним компонентом у мовній картині світу та обгрунтовуються фактори, які впливають на їх утворення. Розглянуто структурно-семантичну та етнокультурологічну характеристику фразеологізмів із соматичним компонентом (на прикладі фразем із компонентом око); проаналізовано основні напрямки сучасних лінгвістичних розвідок, простежено перспективу розвитку етнокультурологічних досліджень фразеологічних одиниць із соматичним компонентом.

Ключові слова: фразеологія, фразеологічна одиниця, фразема, соматизм, мовна картина світу.

Кевлюк И. В. Структурно-семантическая и этнокультурологическая характеристика соматизмов (на примере фразем с компонентом глаз).

В статье освещаются вопросы особенностей функционирования фразем с соматическим компонентом в языковой картине мира и обосновываются факторы, влияющие на их образование. Рассмотрены структурно-семантическая и этнокультурологическая характеристики фразеологизмов с соматическим компонентом (на примере фразем с компонентом глаз); проанализированы основные направления современных лингвистических исследований, прослежена перспектива развития этнокультурологических исследований фразеологических единиц с соматическим компонентом.

Ключевые слова: фразеология, фразеологическая единица, фразема, соматизм, языковая картина мира.

Kevlyuk I. V. Structural-semantic and etnokulturogycal characteristics of the somatisms (for example phrasems with component eye).

The article highlights the issue of the functioning of phrasems with somatic component in the language picture of the world and justifies the factors that affect on their formation. Reviewed the structural-semantic and etnokulturology characteristics of the phrasems with somatic component (for example phrasems with component eye), analyzed the main trends of modern linguistic studies, traced the development of future research etnokulturology phrasems with somatic component.

Key words: phraseology, phraseological units, phraseme, somatism, language picture of the world.

Опрацювання фразеологічного матеріалу різних мов відкриває нові можливості для вивчення проблеми відображення у фразеології 
елементів матеріальної і духовної культури народу, з'ясування іiі різнобічних зв'язків з мисленнєвими та пізнавальними процесами. Фразеологія виступає, на думку лінгвістів, у функції відтворення знаків мовної культури, які беруть участь у трансляції ментальності народу, носія мови. Аналіз сучасної лінгвістичної наукової літератури свідчить про підвищений інтерес до проблем фразеології (Н. Алефіренко, А. Архангельська, О. Андрейченко, В. Васильченко, Н. Дяченко, О. Калякіна, I. Голубовська, О. Присяжнюк, О. Селіванова, Ю. Солодуб, М. Скаб, Н. Скоробагатько, В. Телія, Р. Хайруліна, М. Личук, О. Забуранна, Я. Бакай, Е. Солодухо, М. Лемський, О. Левченко та ін.).

У своєму дослідженні особливостей функціонування фразеологізмів із соматичним компонентом у мовній моделі світу ми опираємося на традиційне тлумачення фразеології, яке бере свій початок у працях В. Виноградова і передбачає широке розуміння цього терміна: стійкі фрази різних структурних типів (словосполучень та речень), що володіють різними семіотичними функціями (ідіоми, фразеологічні сполучення, стійкі фрази біблійного походження та фольклору, фрагменти художніх текстів та ін.) [4, с. 77]. Будь-які лінгвістичні розвідки, зокрема й у галузі фразеології, є неможливими поза історико-культурним контекстом, адже саме в мові яскраво виявляється ментальність нації, ii духовна культура, зумовлені особливостями світовідчуття та світобачення. Мова - невід'ємний символ формування ментальності етносу, засіб інтелектуального й естетичного опанування світу. На думку Е. Сепіра, «мова стає дедалі ціннішим орієнтиром при науковому дослідженні конкретної культури. У певному сенсі набір культурних моделей цивілізації індексується в мові, що виражає цю цивілізацію» [16].

За теорією А. Куніна, основна особливість фразеологічної одиниці - стабільність. Науковець виокремлює структурну, семантичну, морфологічну та синтаксичну стабільність, а також наголошує на сталому вживанні лексичних компонентів [12].

О. Селіванова вважає, що принципи антропометричності фразеологічного фонду мови й аналогізації предметного світу у свідомості людини зумовлюють особливу значущість у номінативних процесах знаків частин людського тіла - соматизмів. Р. Леннекер однією з базових концептосфер свідомості вважає людське тіло, 
позначення частин якого використовують як найменування інших концептосфер [14, с. 60].

Майже всі соматизми $є$ символічними утвореннями, що передаються від покоління до покоління на підсвідомому рівні. Символ у процесі формування фразеологічної одиниці часто набуває національного характеру. Знання світу символів допомагають усвідомити картину реального світу, зрозуміти спосіб мислення наших пращурів, полегшують процес передачі інформації в межах фразеологічної одиниці.

Більшість символів, що лягли в основу творення фразеологізмів i3 соматичним компонентом, $\epsilon$ амбівалентними, що зумовлює виникнення різних значень фразеологічних зворотів i сприяє виникненню синонімічних та антонімічних пар.

В основі творення фразеологізмів із соматичним компонентом наявний i широко представлений український фольклор: народні традиції, вірування та обряди, які також переосмислюються в асоціативному плані і закарбовуються у зворотах із різними нюансами у значенні.

Дослідники виділяють дві виразні групи (ядерну та периферійну) фразеологізмів: фразеологізми 3 соматичним компонентом, що мають високу фразеотворчу активність, i фразеологізми 3 соматичним компонентом, що мають низьку фразеологічну активність. До соматизмів ядерної групи, 3 високою фразеотворчою активністю, належать: голова, серие, душа, рука, нога та око, а до периферійних, що сформувалися асоціативним способом: бік, піт, шия, пуп, тім'я, жили, брови, кістки і т.п. Існує точка зору, що на такий розподіл вплинула i багатовікова опозиція духовного i тілесного, що так само розділяє соматичні компоненти. Духовний світ людини представлений фразеологізмами 3 соматичним компонентом душа, серизе, кров, сльоза, що є маловживаними в мові українського народу порівняно $з$ компонентами тілесного світу [3].

Особливого значення в анатомічній картині світу українського етносу набувають протиставлення духовного та тілесного: духовне пов'язане $з$ головою, мозком, серцуем, душею, а тілесне - $з$ тілом, плоттю, кістками, икірою, хребтом, ребрами, жилами, ногами і руками. Духовне та тілесне, за словами I. Шмельова, «формують нерозривну єдність, разом складаючи одну людину». 
Етнос розглядає тіло людини як форму існування індивідуальності, як умістилище душі. Жива людина повинна в собі гармонійно поєднувати тіло і душу. Цю точку зору підтверджують фразеологізми типу: душа в тілі, душею і тілом, погубити душу 3 тілом, душа прощається з тілом. Однак, у символіці українського етносу тіло нерозривно пов'язане із душею. Тілесний світ $\epsilon$ віддзеркаленням функцій людини, iï руху i сприйняття. Тіло сприймається як форма, умістилище його складових. До основних частин тіла людини відносять такі: око, нога, рука, голова, вухо, язик, лоб та зуб.

Серед зібраного матеріалу найбільшою за кількістю одиниць $є$ група фразем із соматичним компонентом око. Це зумовлено давніми уявленнями людини, оскільки через очі людина отримує значну кількість інформації, а руки й голова виконують найважливіші функції людського організму.

Око - орган зору в людини, усіх хребетних та деяких безхребетних тварин. Так, у російській мові застаріле давньоруське слово око трапляється переважно у складі фразем, запозичених зі старослов'янського: пущзі ока «пильно, дбайливо, ретельно (берегти, охороняти і т. ін.)», у мить ока «моментально, умить, дуже швидко», як зіницю ока «пильно, дбайливо, ретельно», недремне (усевидюче) око «пильний, спостережливий доглядач»; око за око «не уступаючи іншому; не прощаючи, відплатити кому-небудь»; смежить очі «зануритися в сон, заснути». В українській мові цим фраземам відповідають звороти із компонентом око, властиві сучасній літературній мові, у результаті відтінок архаїчності, книжності частково або цілком знімається; наприклад: більше ніж ока (у лобі) (наче ока), оком змигнути, як зіницю ока, як зіницею ока. Архаїзм зіниия у складі фразем зберігає у слов'янських мовах своє затемнене, зв'язане в сучасному вживанні значення.

В. Шевелюк дослідила, що візуальний соматизм око в культурно-міфологічному плані етимологічно сягає лексеми зіниця. Ще Ст. Ульманн розглядав кореляцію й етимологічний зв'язок між поняттями «око», «зіниця», «дівчина» як своєрідні семантичні універсалії у плані типологічної закономірності. Свого часу ще давні греки лексемою *kore позначали зіницюю і дівчину... Берегти як зіницюю ока має значення «високо цінувати, берегти» [23, с. 11]. 
Око - символ розуму й духу, Сонця і зловорожих сил, краси i кохання. На думку А. Голана, символіка ока сягає глибин двадцяти п’яти віків. У Стародавній Греції око було Оком Зевса, в ісламі Оком Аллаха. Ученими доведено, що майже 90\% всієї інформації людина отримує завдяки органам зору. Без очей неможливо бачити, так само як і без світла. Тому в багатьох мовах світу слова на означення ока і світла - історично спільнокореневі (наприклад, фразеологізм світити очима).

«У Ведах, - писав О. Афанасьєв, - сонце називається оком Варуни (неба), у деяких гімнах сонце і місяць уявляються двома очима неба. Верховний бог германців Один (Водан) називався однооким» [1].

Око може випромінювати добро і зло. Також око є символом усебачення, з ним пов'язані світло й мудрість [17]. Існує велика кількість фразеологізмів, що підкреслюють позитивні риси характеру людини: світлі очі, дивитися на світ ясними очима, очі так $і$ світяться.

У народній естетиці, око є символом привабливості та краси, але водночас воно символізує вдачу і заздрість, жадібність і нахабство. За дослідженням Жайворонка, око є також об'єктом численних вірувань і повір'їв, адже за допомогою ока людина може вплинути на долю іншої людини, особливо негативно (звідси зочити, тобто нашкодити, навести вроки за допомогою очей, погляду). Оком дня наші предки називали Сонце, очима ночі - Місяць і зорі, i, навпаки, людські очі порівнювали із Сонцем і Місяцем. 3 очима завжди ототожнюються вікна, порівняймо, наприклад, народну загадку про око: «Стоїть палата, навколо мохната, одне вікно, і те мокре». Різнокольорові очі - ознака належності до нечистої сили; особливі властивості приписують очам деяких тварин: заворожувальну силу має погляд вовка, коли він першим подивиться на людину. У результаті переосмислення цих вірувань утворився фразеологізм вовче око, який вживається на позначення злої, поганої людини, що має негативний вплив на все, чого тільки торкнеться: подивиться на дерево - воно враз засихає; погляне на свиню з поросятами - вона неодмінно їх з'їсть; подивиться на курчата - вони виздихають; недобре око спричиняє хвороби, збитки й різні нещастя; це не залежить від волі людини. В усній народній творчості такі очі зображували під густими зрослими бровами, вони були чорні або запалі, вирячені, косі або просто мали назву заздрісні: Бійся чорних та карих очей [11, с. 416]. 
Погляд жаби теж наводить причину або випадання зубів; магічну силу мають косі очі зайця, вони можуть зурочити, наслати безсоння або сонливість, викликати пожежу. Народний афоризм Oчi не бачать - серие не болить виражає силу впливу зорових вражень на почуття людини, порівняємо синоніми: очі важкі, вогненні, гарячі, глибокі, гострі, іскристі, променисті, пронизливі, сяючі, яскраві; погляд бездонний, блискучий, важкий, відкритий, гарячий, гіпнотичний, глибокий, гнівний, гордий, гострий, жагучий, журливий, зіркий, іскристий, палкий, пекучий, пломеніючий, променистий, шалений. Пор.: В очі лис, поза очі біс (прислів'я); В чужім оці порошинку бачим, а в своїм і поліна не примічаєш (прислів'я); Не доглянеш оком, то вилізе боком (прислів'я); Рученьки терпнуть, злипаються віченьки (П. Грабовський); Лізе в вічі мов оса (М. Номис); Соньки-дрімки у віченьки (М. Максимович); у сполученні: Геть з-перед очей! уживається як лайливий вираз на означення бажання негайно прогнати, вигнати кого-небудь, аби його більше не бачити; 3 очей сталося - зочено, зурочено; $i$ в вічі не бачити - ніколи не бачити або не мати чого-небудь; мороз з очима - сильний мороз; позичати в сірка очей- соромно в очі кому-небудь дивитися [11, с. 416].

На думку багатьох учених, ще десятки тисяч років тому існували численні вірування про погане око. Зокрема, про це свідчать фігури ідолів без очей, або з пов'язкою на обличчі. У грецькій міфології були страшні потвори Горгони, погляд яких убивав усе живе. У слов'ян подібний спопеляючий погляд мав страшний Вій. В античній міфології відомий образ страшного чудовиська Василіска, який поглядом нищив трави, скелі, людей [17]. Ці вірування закарбувалися у фразеологічних зворотах, що позначають людські вади: очима пропікати; очі, темніші ночі; завидющі очі; з лихих очей; блудити очима; лудити очі тощо.

Символ недремного ока - метафорично-символьної назви Всевишнього - поширювався і у християнській літературі. Із часом даний символ став основою для творення фразеологізму недремне око, що значить «постійний нагляд з боку».

У давнину вирізняли і сонячне око. Воно спричиняло неврожай, посуху, хвороби; від блискотливого ока Перуна утворювалися пожежі та смерть. Із часом ці уявлення перейшли на суб'єкта. Очі злої людини могли навести порчу, навроки, наслати пристріт, тобто зустріч із нечистою силою. 


\section{СТРУКТУРА I СЕМАНТИКА МОВНИХ ОДИНИЦЬ}

За станом райдужки ока медики ставлять діагноз людини, вказують на хвороби, які їй загрожують. Деякі лікарі запевняють, що все, що відбувається в організмі людини, залишає свій відбиток на ірисі (латинською мовою око) Це також сприяє утворенню різноманітних фразеологічних сполук.

Крім спектру зорового сприйняття, фраземи з компонентом око позначають спостережливість або уважність: око спинилось, втопити очі, впитися очима; а також досвідченість та кмітливість: гостре око, бите око, око не дрімає, вірне око, що теж пов'язане з функціями ока.

У фразеологічних зворотах метафоричні компоненти представляють уподібнення в етносвідомості ока до рухливого предмета, який є найбільшою цінністю людини: око біжстьь, очі бігають, скидати очима, очі розбігаються, побігти очима, обводити очима, очі рогом лізуть, водити очима, око губиться, око впало, берегти як своє око, ковзати очима, очі блукають (лізуть, лазять).

Очі - це орган зору, «бачення», саме тому у фразеології відображена здатність очей (зрачків) до руху: обвести очима, зміряти очима (поглядом), відвести очі, витріщитти очі і т. ін. Очі можна відкрити, закрити, вилупити, вирячити, витріщити, примружсти. Ними можна моргати, пропікати, вбирати, вести, дрімати, міряти, обводити, обхопити, світити, хлопати, блимати, обертати, блудити, блукати, свердлити, обводити, хапати, впиватися, знизувати, витріщати, вилупляти, виїдати, стріляти, маячити, колоти, заворожувати, пожирати. Невипадково більшість соматизмів із компонентом око відносяться до фразеологічної концептосфери «Дії людини»: не зводити очей, вилупити очі і т. ін.

Уявлення про рухливість ока доповнюється в наївноанатомічній картині етносу враженнями про здатність очей випромінювати світло, що стає експресивним позначенням психоемоційних, рідше - фізіологічних станів людини залежно від конотації дієслів чи спектру знаків вогню, світла. Це зумовило утворення фразеологізмів типу: аж вогні в очах, аж іскорки в очах замигтіли, іскри сиплються з очей, очі заіскрилися, очі запалали, очі горять, очі вогнем запалали, блискати очима, очі розгоряються, очі так $і$ світяться, кресати очима, бісики іскряться в очах, метати іскри з очей, очі мечуть блискавиці. Фразеологізми обпікати очима, засвітити очима, що вживаються на позначення негативних дій людини, теж утворюються за цим зразком. Утрата властивостей ока

๑) І. В. Кевлюк, 2012. 
бачити світло сприймається як утрата оком своєї основної функції. Цей процес відображають фраземи типу: в очах рябіє, в очах замигтіли метелики, в очах жовтіє, світ в очах мутиться, в очах чорніє, в очах темно, свічки в очах засвічуються, туман в очах, круги літають в очах, що позначають утрату здатності гарно бачити [3].

Іноді очі суб'єкта асоціюються 3 гострим предметом, що відображено в фразеологічних зворотах: свердлити очима, гостре око, гострити око, мати гостре око, простромити очима, влучати в око, колоти очима, що позначають докір або застережливе ставлення.

Фраземи з компонентом око поповнюють ще одну фразеологічну концептосферу дієсловами 3 процесуально-динамічною семантикою простору і стану: куди очі поведуть, куди очі покажуть, куди очі бачать, куди очі дивляться, куди очі сягають, куди не кинь оком, світ за очі.

Отже, як стверджує Р. Вайнтрауб, фразеологізми з соматичним компонентом становлять біля 30 \% фразеологічного фонду будь-якої мови [2, с. 162]. Проаналізовано, що домінантним компонентом фразеологізмів із соматичним компонентом є соматизм - назва органу або частини тіла людини (науковці нараховують більше 50 одиниць). Фразеологізми 3 соматичним компонентом різні за кількісним складом. Соматизми належать до найдавнішого шару лексики будьякої мови і характеризуються високою продуктивністю у творенні одиниць вторинної номінації, які репрезентують значний фрагмент мовної картини світу народу. Важливість очей як органа зорового сприйняття і як дзеркала душі знаходить місце в багатьох стійких словосполученнях української мови. Підсумовуючи, можна зазначити, що соматична лексика i, зокрема, іiі використання у фразеології має широке поле для подальших досліджень.

\section{Література}

1. Афанасьєв О. Дерево життя / О. Афанасьєв. - М., 1983. - С. 61.

2. Вайнтрауб Р. М. Опыт сопоставления соматической фразеологии в славянских языках / Р. М. Вайнтрауб // Труды Самарканд. ун-та. Нов. сер. Вып. 288. Вопросы фразеологии. - № 9. - Самарканд, 1975. - С. 162.

3. Важеніна О. Фразеологізми з соматичним компонентом: семантичний та етнокультурологічний аспекти / О. Важеніна, А. Куцева // Донецький вісник Наукового товариства ім. Шевченка : Східний видавничий дім, 2010. - С. 23-33.

4. Виноградов В. В. Избранные труды : Лексикология и лексикография / В. В. Виноградов. - М., 1977. -77 с.

5. Васильченко В. М. Статусна зміна зовнішності людини та ії відображення українськими обрядовими фразеологізмами / В. М. Васильченко // Українська мова. 2010. - № 1. - C. 67-81.

๑) І. В. Кевлюк, 2012. 
6. Васильченко В. Н. Этнофразеологизмы точки пересечения этнокультуры и этноязыка / В. Н. Васильченко // Основные вопросы лингвистики, лингводидактики и межкультурной коммуникации [Текст] : сборник научных трудов по филологии / отв. ред. Г. В. Рябичкина. - Астрахань : Издательство : Сорокин Роман Васильевич, 2008. - № 2 (2). - С. 32-38.

7. Григоренко Т. В. Етнокультурна реконструкція фразеології / Т. В. Григоренко // Наука і сучасність : зб. наук. праць Національного педагогічного університету імені М. П. Драгоманова. - К., 2004. - С. 197-203.

8. Срмоленко С. Я. Фольклор і літературна мова / С. Я. Срмоленко. - К., 1987. -245 с.

9. Жайворонок В. В. Українська етнолінгвістика : деякі аспекти досліджень / В. В. Жайворонок // Мовознавство. - 2001. - № 5. - С. 48-63.

10. Жайворонок В. В. Українська етнолінгвістика : Нариси / В. В. Жайворонок. К., 2007. -262 c.

11. Жайворонок В. Знаки української етнокультури : [словник-довідник] / В. Жайворонок. - К., 2006. - 703 с.

12. Кунин А. В. Курс фразеологии современного английского язика / А. В. Кунин. М. : Высшая школа, 1967. -250 с.

13. Лингвистический энциклопедический словарь / [гл. ред. Ярцева В. Н.]. - М. : Сов. энциклопедия, 1990. - 683 с.

14. Селіванова О. Нариси 3 української фразеології (психокогнітивний та етнокультурний аспекти) / О. Селіванова. - К. - Черкаси : Брама, 2004. - 276 с.

15. Селіванова О. Сучасна лінгвістика : [термінологічна енциклопедія] / О. Селіванова. - Полтава : Довкілля - К, 2006. - 716 с.

16. Сепир 3. Избранные труды по языкознанию и культурологи / 3. Сепир. - М., 1993. - C. 47.

17. Словник символів / [укл. : О. І. Потапенко, М. К. Дмитренко, Г. І. Потапенко та ін.]. - К. : Редакція часопису «Народознавство», 1997. - 156 с.

18. Стернин И. А. Методика иследования структуры концепта / И. А. Стернин // Методологические проблемы когнитивной лингвистики : Научное издание / [под ред. Стернина И. А.]. - Воронежский государственный университет, 2001. - С. 58-65.

19. Таланчук О. Духовний світ українського народу / О. Таланчук. - К., 1992. C. $26-28$.

20. Ужченко В. Д. Фразеологічний словник української мови / В. Д. Ужченко, Д. В. Ужченко. - К. : Освіта, 1998. - 224 с.

21. Філіпчук М. В. Етносимволіка мовних одиниць в українському обрядовому дискурсі : автореф. дис... канд. філол. н. / М. В. Філіпчук. - К., 2007. - 20 с.

22. Фразеологічний словник української мови : у 2 кн. / [укл. : В. М. Білоноженко та ін.]. - [2-е вид.]. - К. : Наукова думка, 1999.

23. Шевелюк В. А. Контрастивна семантика фразеологічних одиниць із соматичним компонентом: лінгвокультурологічний підхід (на матеріалі іспанської та української мов) : автореф. дис... канд. філол. н. / В. А. Шевелюк - К., 2009. - 22 с.

Стаття надійшла до редакції 02.12.2012 p. 